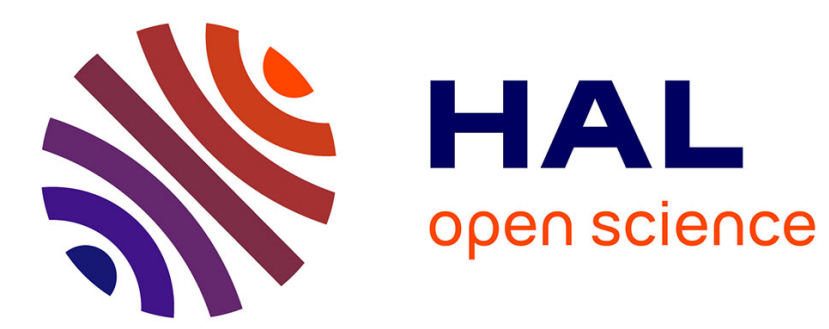

\title{
The Effects of CEO Pay Transparency in France: Benchmarking, 'Catching-Up', and Outsider Scrutiny \\ Lionel Almeida
}

\section{To cite this version:}

Lionel Almeida. The Effects of CEO Pay Transparency in France: Benchmarking, 'Catching-Up', and Outsider Scrutiny. 2016. hal-02102818

\section{HAL Id: hal-02102818 https://hal.science/hal-02102818}

Preprint submitted on 19 Apr 2019

HAL is a multi-disciplinary open access archive for the deposit and dissemination of scientific research documents, whether they are published or not. The documents may come from teaching and research institutions in France or abroad, or from public or private research centers.
L'archive ouverte pluridisciplinaire HAL, est destinée au dépôt et à la diffusion de documents scientifiques de niveau recherche, publiés ou non, émanant des établissements d'enseignement et de recherche français ou étrangers, des laboratoires publics ou privés. 


\title{
The effects of CEO pay transparency in France: Benchmarking, 'catching-up', and outsider scrutiny"
}

\author{
LIONEL ALMEIDA ${ }^{\dagger}$
}

\begin{abstract}
The study investigates the evolution of CEO pay after the implementation of new disclosure rules in France. It opposes a managerial labor market view in which firms compete for CEO talent, and a governance institutions view that embraces managerial power, outrage constraint, and agency issues. The findings first show that closely-monitored and below-average CEOs make the most of benchmarking to catch up to their peers. The catch-up effect is partly driven by competition for talent but also by imitation and perceived fairness. Second, public disclosure places CEO pay under outsider scrutiny, producing two distinct effects: most powerful and above-average CEOs receive lower pay rises, and minority shareholders pressure firms into rising bonuses for all CEOs. Overall, transparency yields a convergence of pay levels and higher ratios of bonuses.
\end{abstract}

JEL: G32; G34; L22

Keywords: CEO pay, benchmarking, managerial market, managerial power, corporate control

\section{INTRODUCTION}

CEO pay transparency allows top executives and directors to benchmark pay practices in other comparable firms. However, the benchmarking process after the implementation of new pay transparency rules is expected to yield different effects depending on the theoretical background one refers to. Apart from large listed American companies, transparency requirements mostly took hold in the 2000s in financially developed countries. Specifically, disclosure of individual executive pay has been required by law since 2001 in France. Based on this recent pay disclosure requirements, this study aims to investigate the effects of transparency on the evolution of CEO pay, and contributes to the debate on whether this evolution is efficient and responds to forces at play in the labor market for CEOs, or whether the evolution is driven by corporate governance issues.

\footnotetext{
* Acknowledgements: This paper benefited from very helpful comments by Virginie Coudert, seminar participants at EconomiX (University of Paris Ouest), participants at the SASE 27th annual conference and the 13th International Paris Finance Meeting. The usual disclaimers apply.

† EconomiX-CNRS, Université Paris Ouest Nanterre - La Défense.
} 
In a managerial labor market approach, benchmarking is a useful tool that contributes to an efficient CEO pay-setting process in the context of competition for talent (Holmstrom and Kaplan, 2003; Bizjak, Lemmon, and Naveen, 2008). As such, the use of peer groups may yield an efficient labor market-driven contagion effect. The contagion effect occurs when managerial pay grows in peer firms, and the directors of a given firm with unchanged characteristics are incited to adjust to the market talent's price if they are willing to retain their incumbent CEO, or attract and hire a new external one (Ezzamel and Watson, 1998; Bizjak et al., 2008; Bereskin and Cicero, 2013). The contagion effect is thus driven by efficient market forces while competing for CEO talent. In this framework, Gabaix and Landier (2008) formulate a theory (hereafter referred to as the "GL model”) in which the contagion is driven by the "size of stakes" in the managerial market (Gabaix, Landier, and Sauvagnat, 2014).

A number of other approaches based on corporate governance issues provide alternative explanations for the evolution of CEO pay. They relate to forces at work in corporate governance institutions and are referred to as the governance institutions view in this paper. They encompass the effects of managerial power and pressure from outsider scrutiny.

The managerial power approach suggests that corporate insiders manipulate the benchmarking process to justify pay rises. Specifically, because of interlocks and reciprocal interests with directors (Kramarz and Thesmar, 2013), powerful CEOs can influence the constitution of peer groups so that comparison firms are at the top of the pay distribution (DiPrete, Eirich, and Pittinsky, 2010). Directors tend to condone such practices as they may benefit from these pay rises themselves: some of them are also top executives in other firms and use similar benchmarking processes, so that pay rises in firms they monitor may in turn legitimate their own pay adjustment as a top executive (Faulkender and Yang, 2010). Consequently, these practices lead to an upward ratchet effect: median pay in peer groups goes up year after year, and influential CEOs in poorly-governed firms use it unendingly to justify higher pay (Ezzamel and Watson, 1998).

Nevertheless, pay transparency also places the pay-setting process under outsider scrutiny, from which two distinct effects can be expected: outrage constraint and agency issues. First, increasingly higher pay packages may create some "outrage costs" in the form of bad reputation from the public or financial retaliation from shareholders (Bebchuk, Fried, and 
Walker, 2004). Pay transparency may then restrain the evolution of pay for above-average CEOs. Second, minority shareholders suffer information asymmetries and it is expected that activist investors use the newly publicly available data to cope with agency costs and put pressure on directors to increase the pay-performance sensitivity (Brav et al., 2008; Kaplan, 2008). Thus, outsider scrutiny may also generate higher levels of pay because of increased ratios of contingent-based components (Jensen and Murphy, 1990a; Hartzell and Starks, 2003).

According to these various views from the literature, transparency can yield contradictory effects on CEO compensation. The present paper investigates these competing approaches based on the evolution of CEO pay packages in large listed French companies after the implementation of new transparency requirements and over a twelveyear period. A major feature of ownership structures in continental European firms is the existence of controlling shareholders (La Porta, Lopez-De-Silanes, and Shleifer, 1999). This study uses an original approach that accounts for governance institutions based on the characteristics of these shareholders. More specifically, the effectiveness of their monitoring activities is gauged according to the type and degree of control.

The empirical approach first relies on the size of stakes metric from the GL model, which intends to assess the intensity of competition in the market for CEOs. It is then interacted with various categories of corporate control in order to test for the competing managerial market and governance institutions views. The results do not yet invalidate one or the other approaches. Instead, both perspectives have complementary explanatory power to account for the evolution of CEO pay after new transparency rules came into force. The findings show that the overall rise in CEO pay is consistent with the increasing size of stakes as specified in the GL model, which contradicts the upward ratchet effect expected from the managerial power view. But the evolution of pay differs depending on the type of monitoring, which in turn shows that the evolution is not only driven by market forces.

Allegedly powerful CEOs are actually paid more at a given time in an inter-firm perspective, but their pay has evolved at a lower rate over the sample period in an intra-firm perspective. This result provides support for the "outrage constraint" hypothesis as most powerful CEOs with initially the highest levels of pay received the lowest raises — or even in some cases pay cuts. Conversely, more tightly-monitored CEOs with the lowest levels of 
pay initially, then benefited from the highest increases and caught up to pay practices in comparable firms. In the end, pay transparency progressively imposed since 2001 allowed for benchmarking and brought about convergence and catching-up effects in pay practices.

This convergence is not merely driven by a better functioning of the managerial labor market thanks to benchmarking and improved information on pay practices in other firms. The study shows that benchmarking also provides "face legitimacy" (Hambrick and Finkelstein, 1995) to increase the levels of pay: compensation packages can rise as long as they do not stand out from the levels found in peer groups — whether the firm competes or not for CEO talent - and do not unleash outrage. The contagion effect is then not only driven by competitive factors but also by perceived fairness and social imitation of peers.

Lastly, pay transparency placed CEO compensation packages under outsider scrutiny. First, the costs of public outrage can account for the already-mentioned lower rises for powerful CEOs, but also for receding equity-based plans after their fair value were publicly disclosed. Second, agency issues and pressure from activist outsider shareholders provide a rationale for the overall surge in the ratios of bonuses. The latter actually concerns all firms, whether CEOs are closely monitored or not, and it accounts for the major part of pay increases since public disclosure of compensation packages began.

The remaining of this paper is organized as follows. Section 2 provides the theoretical background and the hypotheses to be tested. Section 3 presents the sample data and the methodology, and section 4 displays the results. The last section concludes.

\section{THEORY AND HYPOTHESES}

\subsection{Market for CEOs against Governance institutions views}

In a managerial labor market perspective, CEO pay is expected to vary according to competition for managerial talent. Gabaix and Landier (2008) suggest that firms' willingness to pay for talent — also termed as the "size of stakes" (Gabaix et al., 2014) — can be accounted for via a market-level size effect, and that it can be measured with the size of a reference firm. The authors define the reference firm as the median firm among those competing for managerial talent. They predict that an incumbent CEO in a firm with a given size receives higher pay when the reference firm size grows: pay levels in other firms grow with their respective own firm-level size effects, the incumbent CEO thus gets improved outside opportunities as the 
size of other firms increases at the market level. Directors are then incited to upgrade the pay of their CEO for retention reasons, and they would also adjust to the going rate if they were willing to attract and hire a new external CEO.

Under this labor market-based view, pay transparency may improve benchmarking and the pay-setting process. But overall, and after controlling for usual CEO and firm characteristics, CEO pay is expected to vary in line with the "size of stakes" as measured with the reference firm size. The first hypothesis is then formulated as follows:

(H1.1) (Market for CEOs): The evolution of CEO pay, all other things equal, is fully explained by the evolution of the reference firm size.

Based on the alternative governance institutions approach, pay transparency provides new information to some relevant agents, and deviations from the expected impact of the reference firm size may occur depending on the forces at work in corporate governance. These forces at work are notably related to powerful CEOs, public outrage, or agency issues from outside minority shareholders. They altogether may have positive or negative impacts on pay. These various potential effects will be further discussed in the following section. They are in a first instance tested for with the following generic hypothesis:

(H1.2) (Governance institutions): The evolution of CEO pay deviates from the reference firm size growth, positively or negatively, depending on the forces at work in the governance of the firm.

\subsection{Hypotheses to test for the types of control}

Most continental European listed companies have a major shareholder in their equity (La Porta et al., 1999). In such countries, as in France, a major feature of governance institutions is the type of control that these major shareholders exert. Specifically, the existence of a controlling shareholder is key in the process of compensation design, in management monitoring, and in counterbalancing the CEO's potential influence over the board. A large array of literature shows that effective monitoring activities induce both lower levels of pay and lower ratios of contingent-based components, whether monitoring is accounted for through the existence of large shareholders (Beatty and Zajac, 1994; Mehran, 1995; David, Kochhar, and Levitas, 1998; Core, Holthausen, and Larcker, 1999; Cyert, Kang, and Kumar, 2002) or of some board characteristics (Lambert, Larcker, and Weigelt, 1993; Chhaochharia and Grinstein, 2009). 
The present study relies on the existence of controlling shareholders and their characteristics to gauge the effectiveness of management monitoring and categorize various types of corporate control. The categories of corporate control are then used to test for two sets of hypotheses related to the consequences of pay transparency. The first one refers to the managerial labor market and the second to governance institutions.

In the first set of hypotheses, three variants of the market-based perspective are distinguished. The first one assumes a perfectly efficient functioning of the market for CEO talent, the second waives the assumption of efficiency and admits imperfect information, and the third one considers the effects of transparency on CEOs not participating in the managerial market.

First, under the hypothesis of an efficient market for CEOs, the type of control should not alter the impacts of the going rate for talent on pay. Thus, if a given type of control explains different levels of pay across firms in a given year, these inter-firm differences should be maintained over time, and the size of the reference firm is expected to evenly impact all firms by the same factor.

Under the second variant with imperfect information, the types of control that were below and above the going rate for talent initially, ceteris paribus, adjust through a benchmarking process as they get information about their counterparts due to the new disclosure rules. CEO pay disclosure allows for a better functioning of the market for CEOs through effective benchmarking and market-price comparisons (Holmstrom and Kaplan, 2003; Bizjak et al., 2008), which would then result in a convergence of pay practices among the different types of control.

The third variant of the market-based view considers some CEOs who have specific ties to their firm and hence do not take part in the competition for managerial talent. It is then expected that the former two variants have no impact on these CEOs. Owner- and familyCEOs can be considered as having such ties to the firm because of their personal or family wealth invested in it. Owner-CEOs control the firm on their own name. They are often its founder and they typically have a large share of their personal wealth involved in it. Family CEOs are a member of the controlling family but do not necessarily own a large share of equity on their own name. They are however attached to the firm because they fulfill some "family obligations" and have an emotional commitment to the firm (Gomez-Mejia, Larraza- 
Kintana, and Makri, 2003). Both these categories of CEOs are referred to as firm-specific CEOs in the present study. Because of their close ties to the firm, they are not available for outside opportunities and hence do not participate in the managerial labor market. In these cases, the determinants of their pay should only be firm-specific and not influenced by forces at work in the market for CEOs. If not, this would suggest that the contagion effect accounted for through the reference firm size variable is not only driven by market forces. Instead, it may also be driven by nonmarket factors such as perceived inequity and legitimacy issues (Hambrick and Finkelstein, 1995; Nagel, 2007).

On this basis, three hypotheses related to the functioning of the managerial labor market are formulated as follows:

\section{(H2.1) Market for CEOs:}

(H2.1a) (Efficient labor market): CEO pay increases as a factor of the reference firm size growth, regardless of the type of control.

(H2.1b) (Non-perfect information): New disclosure rules facilitate benchmarking and improve the functioning of the market for $C E O$ s, resulting in a convergence of pay practices.

(H2.1c) (Non-competing CEOs): The reference firm size has no impact on owner-and family-CEOs pay, as these CEOs do not participate in the market for CEOs.

In the second set of hypotheses related to governance institutions, it is expected that the average increase in CEO pay would differ according to the type of control, particularly according to the efficiency of management monitoring. These divergences may take several forms according to the forces at work in governance institutions. Hence, three variants are tested for: managerial power, outrage constraint, and agency issues.

First, CEOs may be more powerful in some categories of corporate control, for instance in firms with diffusely-held equity in which no large shareholder can exert influential monitoring. Powerful CEOs may influence the choice of comparison firms in the benchmarking process and select skewed, highly paid peer groups to obtain above-average pay increases (Ezzamel and Watson, 1998; Faulkender and Yang, 2010) and "leapfrog" to the right side of the pay distribution (DiPrete et al., 2010).

Second, pay transparency reveals information about pay practices from one firm to another, and outside stakeholders may use this information to pressure firms that do not comply with their specific expectations. In the case of the outrage constraint hypothesis (Bebchuk et al., 2004), outsiders may pressure firms in which the type of control is associated 
with the highest levels of pay — and presumably with most powerful CEOs — so as to negatively adjust them. Specifically, outside shareholders see excessive levels of pay as a form of private benefit at their expense (DeAngelo and DeAngelo, 2000; Dyck and Zingales, 2004); for their part, unions and public opinion are concerned with inequity within the firm and with rising inequalities in the overall society.

Third, agency issues may arise from outsider minority shareholders, and specifically from activist institutional investors. These shareholders suffer from information asymmetries with insiders that they may overcome by tying CEOs' wealth to performance criteria in their favor (Hartzell and Starks, 2003; Kaplan, 2008; Ertimur, Ferri, and Muslu, 2011). Pay disclosure places the pay-setting process under their scrutiny and they may use the newly available information to pressure insiders into raising incentive-based components. This would result in pay increases because of rising ratios of contingent pay, whatever the type of control. Also, if the reference firm size mostly has an effect on pay levels through higher incentive-based components, then the reference firm might also account for the rising influence of outsider activist shareholders in the financial market, and not only for competition in the managerial labor market as assumed in the GL model.

On this basis, three hypotheses related to the forces at work in governance institutions are formulated as follows:

\section{(H2.2) Governance institutions:}

(H2.2a) (Managerial power): CEO pay increases at a faster rate when the type of control is favorable to managerial influence.

(H2.2b) (Outrage constraint): Poorly-monitored CEOs with the highest levels of pay initially will get belowaverage pay increases.

(H2.2c) (Agency issues): Contingent-based pay increases at a higher rate than expected because of outsider minority shareholders' pressure.

\section{DATA AND METHOD}

\subsection{Specifications and methodology}

\subsubsection{Evolution of pay and market for CEOs}

Hypotheses (H1.1) and (H1.2) are tested for based on the following equation: 


$$
w_{k, i, t}=c_{k}+\sum_{l=0}^{1} \alpha_{k, l} S_{i, t-l}+\sum_{h=1}^{3} \beta_{k, h} C_{h, i, t}+\sum_{i=1}^{N-1} \gamma_{k, i} F_{i}+\sum_{\tau=1}^{3} \rho_{k, \tau} S P_{\tau}+\sum_{l=0}^{1} \omega_{k, l} S^{*}{ }_{t-l}+\varepsilon_{k, i, t}
$$

where $w_{k, i, t}$ stands for CEO pay for firm $i$ in year $t ; k$ takes values $\{1, \ldots, 5\}$ and respectively stands for base salary, cash compensation, total compensation, the ratio of bonus to salary, and the ratio of long-term incentives (LTIs) to total compensation. The first three dependent variables account for the level of pay, and the last two for the structure of pay and its incentive-based components. Cash compensation is defined as the sum of base salary and bonuses. Total compensation is the sum of cash compensation and LTIs. LTIs are comprised of stock-options, stock grants, and deferred incentive plans. Stock-options are valued as the number of options granted multiplied by 25 percent of the exercise price ${ }^{5}$. As a whole, LTIs are most often not granted on an annual basis and may amount to large values in a given year. For this reason, their values are averaged over two years and are then winsorized so that they do not represent more than 57 percent of total compensation ${ }^{6}$. A number of firms do not provide their CEOs with bonuses and/or LTIs either during the entire period or in some given years. Hence, the two dependent variables for the structure of pay (ratios of bonus and LTIs) are censored from below at zero. The ratio of LTIs is also censored from above as it is winsorized. Consequently, a Tobit model is applied for these two dependent variables.

Control variables include firm size, CEO characteristics, and firm-specific fixed-effects. First, the size of the firm is denoted $S_{i, t-l}$ and it is either measured with sales or with total firm value (i.e. market value of equity, plus debt). It is also either measured with current or lagged values (i.e., $l=\{0,1\}$ ). The choice of the relevant lag is based on the pay-setting process. Typically, directors on the board define pay packages in the following way: base salaries and performance targets are set at the beginning of the fiscal year, LTIs are granted in the course of the fiscal year, and ratios of bonuses are decided based on target achievements at year-end. Given this typical process, salary is better accounted for with lagged values, LTIs with both current and lagged values, and bonuses with current values?

\footnotetext{
5 This discount valuation method yields values in the same range as more sophisticated models (Lambert et al., 1993) and is found to be more reliable in some studies (Finkelstein and Boyd, 1998). Using fair value of stock-options as disclosed in annual reports after 2007 provides similar results and significance in the following regressions.

${ }^{6}$ Fifty-seven percent is the top decile of the ratio in the sample. Hence if the ratio of LTIs to total compensation is higher, the value of LTIs is set to Cash compensation*0.57/(1-0.57), so that the ratio is capped at 57 percent.

${ }^{7}$ In the database, the bonus entered for year $\mathrm{N}$ is the bonus granted in respect of year $\mathrm{N}$ (actually most often paid in $\mathrm{N}+1$ ). It is thus related to the current firm value and other performance variables in the database for a given year $\mathrm{N}$.
} 
Second, three indicator variables, denoted $C_{h, i, t}$, account for CEO characteristics. They respectively take a value of one if the $\mathrm{CEO}$ also chairs the board of directors, if he/she is the founder and not the main stockholder of the firm, and if he/she is a new insider CEO; they respectively take a value of zero otherwise. Building on Hambrick and Finkelstein (1995), a new insider CEO is defined as a CEO with only one or two years of tenure but who had been in the firm for more than two years when nominated.

Third, firm-specific fixed-effects, denoted $F_{i}$, capture time-invariant inter-firm variances. Hence, coefficients associated with the other independent variables essentially capture the remaining intra-firm variances, and the specification estimates the impacts within firms of the independent variables on CEO pay. Lastly, $c_{k}$ is an intercept and $\varepsilon_{k, i, t}$ are the residuals of the regression. All nominal variables are expressed in 2007 constant euros (using the consumer price index of INSEE, the French national statistics institute) and are logtransformed.

The variables of interest are the time-specific fixed-effects and the reference firm size. First, the time-specific dummy variables divide the sample into three sub-periods, denoted $S P_{\tau} . S P_{1}$ takes value one for the years falling in the first sub-period (2001-2004), zero otherwise, and similarly for $S P_{2}(2005-2008)$ and $S P_{3}$ (2009-2012). The choice of subperiods instead of year dummies allows one to focus on the observation of CEO pay trends after pay transparency, and to neutralize the effects of annual pay-performance sensitivities that are beyond the scope of this study. Also, a number of firms progressively complied with new transparency rules in the years following 2001, i.e. over $S P_{1}$, and disclosure rules evolved during these first years so that firms progressively disclosed detailed information about base salaries and bonuses, and not merely the aggregated amount of cash pay. As a consequence, the impacts of new transparency rules implemented over $S P_{1}$ are mostly expected during $S P_{2}$. Lastly, firms have been required to disclose the fair value of stock-based plans since 2008. Before that year, only the characteristics of the plans (number of stock-options, exercise price, duration...) were to be disclosed, so that professional outsiders such as other firms or institutional investors were already able to estimate their fair values. Their disclosure since 2008 then mostly reveals new information to other outsiders (non-professional investors, unions, public opinion) and its effects are expected during $S P_{3}$. 
The second variable of interest is the size of the reference firm, denoted $S^{*}{ }_{t-l}$. It is measured with its sales or firm value, and with its current or lagged values depending on the pay component as previously described for the sample firm size. In their study, Gabaix and Landier (2008) define the reference firm as the $250^{\text {th }}$ firm in the S\&P 500 index for a given year. Similarly in the present study, it is defined as the $60^{\text {th }}$ firm among those included in the SBF 120 index in a given year. According to the GL model, this variable is a proxy for the evolution of the "size of stakes" and the intensity of competition for talent in the market for CEOs. Under hypothesis (H1.1), this variable is expected to account for all CEO pay variations in $\mathrm{SP}_{2}$ and $\mathrm{SP}_{3}$ that are not yet explained by $\mathrm{CEO}$ and firm characteristics, so that sub-period indicators should no longer have coefficients different from zero when the reference firm size is included in the regression. Alternatively, under hypothesis (H1.2), coefficients associated with $S P_{2}$ and $S P_{3}$ are expected to remain significantly different from zero because of other nonmarket-driven factors.

\subsubsection{Types of control and governance institutions}

The effects of governance institutions on the evolution of CEO pay are taken into account by differentiating the impacts of the reference firm size from one type of corporate control to another. I use two typologies to characterize corporate control, they are respectively based on the degree of control and on the identity of the controlling shareholder. Both typologies are defined in Table 1. The controlling shareholder and its degree of control are defined based on the findings of Almeida (2015) in the context of large listed French companies. Controlling shareholders are investors that own more than 10 percent of the company's equity, i.e. enough interest to exert effective control. Firms that do not have such shareholders are defined as non-controlled. Among controlled firms, a threshold at slightly less than half of equity shares $(45 \%)$ separates minority from majority controls. The second typology refers to the identity of the controlling shareholder and is comprised of seven categories. An earlier study shows that these categories significantly discriminate controlling shareholders in terms of involvement and time horizon, resulting in the design of differentiated CEO pay schemes from one firm to another (Almeida, 2014).

[Insert Table 1] 
These two typologies are aimed at gauging the relative power of the CEO based on the type of management monitoring expected from the controlling shareholder. For instance, the higher the degree of control, the more the monitor is expected to dominate the board of directors and corporate governance decisions. A stronger control markedly reduces the influence of CEOs over the board and their ability to set their own pay. Similarly, some monitors' identities are expected to be associated with more or less powerful CEOs.

To estimate the effectiveness of monitoring and the relative power of the CEO from one type of corporate control to another, I rely on extensive literature showing that where monitoring is efficient, the levels of pay and the ratios of contingent-based pay are lower (Dyl, 1988; Lambert et al., 1993; Beatty and Zajac, 1994; Mehran, 1995; David et al., 1998; Core et al., 1999; Cyert et al., 2002; Chhaochharia and Grinstein, 2009). I then specify the following equation to gauge the relative power and effectiveness of monitoring from one type of control to another, based on their respective cross-sectional impacts on CEO pay packages:

$$
w_{k, i .}=c_{k}+\alpha_{k} S_{i .}+\sum_{j=1}^{2} \beta_{k, j} G_{j, i .}+\sum_{m=1}^{M} \beta_{k, n} I_{n, i .}+\sum_{h=1}^{3} \beta_{k, h} C_{h, i .}+\sum_{x=1}^{X-2} \vartheta_{k, x} T_{x, i .}+\varepsilon_{k, i}
$$

The dependent variable and the variables denoted $S_{i .}$ and $C_{h, i}$ are the same as in Eq. (1), except that the equation is specified with a Between method and the variables are hence averaged at the firm level. This inter-firm specification also leads to drop the firm-specific fixed-effects from Eq. (1). In order to account for some firm characteristics that were formerly captured through fixed-effects, two variables (denoted $G_{j, i .}$ ) are included to respectively account for the firm's age and risk, and some industry-specific fixed-effects (denoted $I_{n, i .}$ ) are also added. The firm's risk is measured with the standard deviation of returns on assets (ROA) over the prior five years (Core et al., 1999; Gomez-Mejia et al., 2003).

Lastly, the variable $T_{x, i}$. stands for the type of control and includes an indicator variable for each of the $X$ categories of corporate control reported in Table 1. Each dummy variable takes a value of one for the corresponding type of corporate control, zero otherwise. For the sake of brevity in the presentation of the results, both typologies are included at the same time. The category of non-controlled firms is omitted and serves as a benchmark. The two other categories of the degree of control and the categories of monitor's identity both respectively 
account for all controlled companies. To avoid creating a unitary matrix, one category from the monitors' identity will also be omitted in the regressions.

\subsubsection{Market for CEOs vs. governance institutions}

Building on the corporate control patterns returned by the previous specification, the following intra-firm specification is then used to measure the specific evolution of CEO pay in each category of corporate control, and to test for the second set of hypotheses (H2.):

$$
\begin{gathered}
w_{k, i, t}=c_{k}+\sum_{l=0}^{1} \alpha_{k, l} S_{i, t-l}+\sum_{h=1}^{H} \beta_{k, h} C_{k, h, i, t}+\sum_{i=1}^{N-1} \gamma_{k, i} F_{i}+\sum_{\tau=1}^{3} \rho_{k, \tau} S P_{\tau}+\sum_{x=1}^{X-2} \vartheta_{k, x} T_{x, i, t}+\omega_{k} \overline{S^{*}}{ }_{t} \\
+\sum_{x=1}^{X-2} \varphi_{k, x} \overline{S^{*}}{ }_{t} T_{x, i, t}+\varepsilon_{k, i, t}
\end{gathered}
$$

The terms of the equation are the same as in Eq. (1), except for the following changes. The equation includes the dummy variables for the types of corporate control as defined for Eq. (2) and denoted $T_{x, i, t}$. These dummy variables are then interacted with the reference firm size. In order to produce straightforward and readable results, the relevant variables for the reference firm size (i.e. sales and/or firm value, in current and/or lagged value) are averaged so that there is one unique variable of interest, denoted $\bar{S}^{*}$. Coefficients associated with the interaction terms (denoted $\varphi_{k, x}$ ) then capture deviations from the impact of the reference firm size (estimated by $\omega_{k}$ ) on the evolution of CEO pay for a given type of control.

Under the efficient labor market hypothesis $(\mathrm{H} 2.1 \mathrm{a})$, the growth of the reference firm size ("size of stakes") should impact the pay of professional CEOs in all firms with a unique factor over time regardless of the type of the controlling shareholder, so that coefficients $\varphi_{k, x}$ should be equal to zero. Conversely, deviations from this expected stable relationship would be in favor of one of the competing hypotheses. Under the non-perfect information hypothesis (H2.1b), transparency and improved information leads to a convergence of pay practices through higher pay rises for the types of control associated with initially lower pays.

These first two hypotheses rely on the assumption from the GL model that the reference firm size is a proxy for the "size of stakes" in the market for CEOs. The relevance of this assumption is tested for via the non-competing CEOs hypothesis (H2.1c). It refers to two categories of control that are associated with non-professional firm-specific CEOs, namely owner- and family-CEOs ("CEO" and "Family CEO" in Table 1). These CEOs cannot be 
deemed as participating in the market for CEOs as they are attached to one specific firm, and their specific ties keep them apart from competition for managerial talent (Gomez-Mejia et al., 2003). Then the evolution of their pay is expected not to be sensitive to the evolution of the "size of stakes", and their associated coefficients $\left(\varphi_{k, x}\right)$ should offset the reference firm size impact $\left(\omega_{k}\right)$. If not, the impact of the reference firm size on CEO pay may have a broader significance than competitive forces in the managerial market.

Alternatively, in a managerial power perspective (H2.2a), powerful CEOs are expected to make the most of transparency to select and benchmark highly-paid peers and justify increases in compensation, leading to a positive coefficient for the associated interaction terms. Conversely, less powerful CEOs would not be able to catch up to their peers by manipulating the benchmarking process, and associated coefficients should be null or negative.

Under the outrage constraint hypothesis (H2.2b), the evolution of pay for powerful CEOs is expected to be opposite to the one expected under (H2.2a). Powerful CEOs are those associated with the highest levels of compensation initially. Public disclosure places their pay under outsider scrutiny and should trigger outrage especially for them. This may then induce a downward pressure and a negative sign for the associated coefficients.

According to the agency issues hypothesis (H2.2c), transparency allows activist outside minority shareholders to pressure firms to adjust to their requirements (i.e. higher shares of pay that are contingent upon performance). If the reference firm size effect mostly leads to higher ratios of contingent-based pay, it may then stand for agency issues stemming from the financial market — instead of competition for talent in the managerial labor market as assumed in the GL model.

\subsection{The data}

\subsubsection{Sample data}

Companies in the sample panel are selected among the SBF 120 index constituents during a period spanning from 2001 to $2012^{8}$. The index consists of the 120 companies with the

\footnotetext{
${ }^{8}$ As long as one company was part of the SBF120 index for at least one year during the period, all available year-observations for this company are included on the panel. Hence, the panel can also account for relatively small firms and include larger spans for intra-firm variances.
} 
highest capitalization and trading stock activity at Euronext Paris. Only French companies (i.e. headquartered in France) were kept on the panel in order to avoid country-specific biases. Some companies were removed because of their specific legal form ${ }^{9}$, or because of aberrant or missing data. In addition, a minimum observation of four years per company is required for the sake of representativeness and to allow for sufficient intra-firm variations. In the end, 131 companies and 1,354 year-observations make up the sample panel over a twelve-year period.

The original database is constructed as follows: CEO characteristics, pay packages, and the identity and characteristics of large shareholders are hand-collected from the annual reports of the companies. Equity shares of large shareholders are complemented with data retrieved from the Thomson One Banker - Ownership database. Accounting and stock market data are retrieved from Datastream.

\subsubsection{Descriptive statistics}

Table 2 provides some descriptive statistics about the sample data, on the entire period in the first Column, and per four-year sub-period in the next three columns. Panel A presents usual statistics for the continuous variables, and panel B presents the means for the indicator variables. All figures (excluding ratios) are expressed in constant 2007 euros.

Over the entire period, the median French CEO receives a salary of 629,000 euros and a bonus of 423,000 euros, the median cash compensation (salary, plus bonus) reaching 1,190,000 euros. On top of that, he/she receives long-term incentives (LTIs) of 311,000 euros. Overall, the median total compensation (cash, plus LTIs) amounts to 1.60 million euros per year.

\section{[Insert Table 2]}

The bonus represents $74 \%$ of the salary, and LTIs $26 \%$ of the total compensation. In the median firm, sales total to 2,626 million euros, market value of equity is 2,669 million euros, and firm's market value ${ }^{10}$ is 3,583 million euros. The average values for firm size are

\footnotetext{
${ }^{9}$ Companies with a SCA status (Société en commandite par actions, i.e. limited partnership with shares) have specific governance bodies and specific managers' pay schemes.

${ }^{10}$ Firm's market value is as calculated by Datastream ("enterprise value" item in the database): Market capitalization + debt + minority interest and preferred shares - total cash and cash equivalents.
} 
much higher than median values which reflects a positively skewed distribution. The same observation applies for LTIs and hence for total compensation, and also appears through the large maximum values for these variables. This feature is handled with log-transformation of all nominal variables in the regressions, and with the above-mentioned trimming for LTIs.

The last three sets of columns in the table show the mean, standard deviation, and maximum values by sub-period for each variable. The statistics show that the average pay consistently increased over the period but that conversely standard deviations consistently decreased, and maximum values decreased from SP2 to SP3. In other words, these figures show an increase in CEO pay levels over time with simultaneously a lower dispersion, which notably takes the form of lower highest values at the end of the period. At this stage, this lower dispersion would be consistent with a convergence of pay practices after new pay transparency rules were implemented, and also consistent with an outrage constraint leading to a downward pressure on the highest levels of pay.

On the entire period, the median value of the reference firm size is respectively 2.29, 2.63 , and 3.55 billion euros in terms of sales, equity value, and firm value. The size of the $60^{\text {th }}$ largest firm increased over the three sub-periods in terms of sales, but it fell in terms of market values (capitalization, and firm value) after the drop in stock market values in 2008.

CEO characteristics are measured with indicator variables, the means of these dummy variables are presented on panel B of Table 2, and they can be interpreted as percentages of firm-year observations. The CEO is also the chairman of the board in more than half of firmyear observations on the sample period, although this situation has declined from $61 \%$ in 2001-2004 to 51\% in 2009-2012, which is consistent with previous studies for French CEOs during the 2000s (Waxin, 2011b; Belot, et al., 2014). The CEO is also the founder of the firm, but not the controlling shareholder, in about 3\% of firm-year observations, with no substantial changes from SP1 to SP3. The fraction of firm-year observations with new insider CEOs is stable over time (about 5\%).

About $24 \%$ of firms are non-controlled in the sample with a peak at $28 \%$ during SP2. The $76 \%$ remaining firms are either minority- $(40 \%)$ or majority-controlled $(36 \%)$. The last rows of the table show the distribution of these controlled firms per category of monitor's identity. 


\section{RESULTS}

\subsection{Firm and CEO characteristics}

Table 3 presents the results of the regressions specified in Eq. (1). All regressions include firm-specific fixed-effects to capture time-invariant inter-firm variances, the results thus focus on the intra-firm effects of the independent variables.

Firm size is a major explanatory variable for the level and structure of CEO compensation. As previously described, the different components of pay are determined at various points of time before, during and after a given fiscal year, these patterns determine the choice of current and/or lagged values for firm size ${ }^{11}$. The results also show that sales have a stronger explanatory power for salary, while firm value better predicts the variable pay components.

The dummy variable for CEO duality (CEO is chairman) has a significantly positive impact on salary but a significantly negative effect on the ratio of LTIs. Their influential position on the board of directors thus allows them to induce the design of a more secured total pay. This is consistent with Beatty and Zajac (1994) who show that CEOs are riskaverse and prefer non-contingent pay packages, but this is contrary to the results of Cyert and coauthors (2002) who find higher equity-based pay for these CEOs in U.S. public firms. Next, CEOs who are the founder of the firm but do not hold significant shares of equity (CEO is founder) receive a premium for their specific contribution to the firm in the form of higher salaries and bonuses, but receive similar LTIs as non-founder CEOs. Lastly, new insider CEOs receive significantly lower cash and total pay. This is consistent with the findings of Hambrick and Finkelstein (1995) who show that newly appointed CEOs accept lower compensation packages compared to their predecessors when they are internally promoted because of the status and power associated with becoming CEO inside the firm - while externally hired CEOs receive similar levels of pay as their predecessors as the firm needs to attract them and secure their services.

[Insert Table 3]

11 Table 3 only includes the relevant firm size variables for each pay component. Unreported regressions show that the omitted ones (including the non-displayed current value of sales) have no substantial effect if added. 


\subsection{Evolution of CEO pay and size of stakes}

The enforcement of compulsory pay transparency for individual executives in listed French companies since 2001 is expected to yield significant changes in pay practices. Regressions are run to estimate the evolution of CEO pay over the three sub-periods and are presented in Columns 1, 3, 5, 7, and 9 of Table 3. SP1 (2001-2004) is omitted and serves as a benchmark for SP2 (2005-2008) and SP3 (2009-2012).

All coefficients associated with the sub-period indicators are significantly positive at the one percent statistical level, except for the ratio of LTIs. Hence, CEO pay rose beyond its expected evolution for most pay components, after controlling for firm size, CEO characteristics and firm-specific fixed-effects. Specifically, salary increased by about 12 percent between SP1 and SP3 (Column 1); this rise was relatively continuous as it had already increased by about six percent by SP2 ${ }^{12}$. The ratio of bonus to salary increased by about 19 points between SP1 and SP3, but the increase had mostly occurred by SP2 with about 16 points already (Column 3). The ratio of LTIs presents a different picture as it remained relatively stable from SP1 to SP2 (increase by two points), but then significantly decreased to end up at about six points lower in SP3 compared to SP1 (Column 7). These results for the ratios of contingent-based pay are also consistent with descriptive statistics presented in the last rows of (Columns 4 and 5): the average ratio of bonus increased from 65 to 79 percent and the ratio of LTIs decreased from 24 to 21 percent between SP1 and SP3.

Overall, cash and total compensation increased by about 39 and 30 percent, respectively, between SP1 and SP3 (Columns 5 and 9). The decrease of the ratio of LTIs accounts for the lower increase in total compared to cash compensation. In both cases, most of the increase already occurred by SP2 (25\% out of $39 \%$, and $26 \%$ out of $30 \%$, respectively), i.e. after the implementation of new pay transparency rules during SP1.

The reference firm size is included in the regressions in a second step and as specified in Eq. (2). The results are presented in Table 3 (Columns 2, 4, 6, 8, and 10) ${ }^{13}$. They show that the reference firm size has a strong explanatory power to explain the variations of the levels of pay (columns 2, 6, and 10), as the sub-period coefficients are no longer different from zero. This result provides support for the market-based hypothesis (H1.1): the "size of

\footnotetext{
12 The dependent variable is log-transformed, sub-period coefficients can then be interpreted as deviations in percentages.

13 Table 3 only includes the reference firm size variables that contribute to explain pay variations; unreported regressions show that the omitted ones have no substantial effect when added and their coefficients are not statistically different from zero.
} 
stakes" accounts for CEO pay rises that are not explained by usual firm and CEO characteristics.

As for the structure of pay, the sub-period coefficients are negative but not significant at usual thresholds for the ratio of bonus (Column 4), but it is significantly negative in SP3 for the ratio of LTIs (Column 8). Unreported regressions with year dummies instead of subperiods show that these negative coefficients include the effects of the financial crisis in 2008 and 2009. This can account for the negative but not significant coefficient in SP2 (20052008) and SP3 (2009-2012) for the ratio of bonus. But after 2009, bonuses go back up while the negative coefficients for the ratio of LTIs are maintained and even reinforced. The overall decrease of equity-based pay then does not seem to be attributable only to the crisis. As

already mentioned, the fair value of stock-options and stock grants has been publicly disclosed since 2008 (only the characteristics of the plans were disclosed before). The specific variation of LTIs in the last sub-period may then be related to the implementation of this new transparency rule. At this stage, this remaining time effect after controlling for the reference firm size hints at non-market forces and it provides some support for the alternative hypothesis (H1.2).

\subsection{Cross-sectional impacts of the types of control}

As a preliminary stage, CEO pay components are regressed on the indicator variables for the categories of control with a between method, as specified in Eq. (2). The results are presented in Table 4. The dummy for non-controlled firms is omitted to serve as a benchmark. As for the identity of monitors, several categories from the typology presented in Table 1 did not exhibit any specific patterns (not reported) in the intra-firm analysis that follows. For simplicity, they are gathered in a category termed as Others that includes the following categories: Active family, Parent company, and Investment company. This category is chosen as the omitted variable among the categories of the monitor's identity.

\section{[Insert Table 4]}

This cross-sectional analysis shows that firms with majority controlpay an about 40 percent lower total compensation to their CEOs, compared to non-controlled firms (Column 5). The negative effect is observed for all components of pay; it is statistically significant for cash pay 
(Column 3) and the ratio of LTIs (Column 4), but not significant at usual thresholds for salary (Column 1) and the ratio of bonus (Column 2). On top of that, the specific impact of CEO- and State-controlled firms is also negative and significant. For instance, firms controlled by the public sector are associated with a lower total compensation of about 68 percent compared to the omitted Others firms, ceteris paribus - also, in the event the state holds a majority position, this impact comes in addition to the -0.40 degree of control impact (Column 5).

CEO-controlled firms are a specific case as CEOs are also their own monitors. They receive the lowest levels of pay despite being in a powerful position. This can be explained by their significant equity positions from which they get a proportional share of the dividend payouts; as such, it is unnecessary to provide them with a high level of salary or with contingent-based pay ${ }^{14}$. Family CEOs are also in a specific influential position as they are a member of the controlling family and hence have family ties with their monitors. In spite of that, the level of their total pay (Colum 5) is similar to the one found in the omitted Others category, but it is comprised of a significantly higher base salary (Column 1) and significantly lower ratios of contingent-based pay (Columns 3 and 4). They indeed need lower incentives as their status and identity are already closely attached to the firm (McConaughy, 2000). They also get higher levels of salary and total pay than owner-CEOs, which can easily be explained by the substantially lower share of dividend payouts they receive as, by definition according to the typology, they only hold a minority share of the family equity position.

Conversely, non-controlled firms, and to a lesser extent firms with minority control, provide higher levels of pay compared to the above-mentioned categories. Also, the specific impact of passive families is positive and significant: they provide their CEOs with cash and total compensation that are about 54 and 75 percent higher, respectively, all other things being equal.

These inter-firm results are used in this study to characterize governance institutions, in terms of monitoring and managerial power. They show that CEOs are more powerful and have higher pay in non- and minority-controlled companies, and in companies with passive families as controlling shareholders. Conversely, CEOs are less influential in majority- and

\footnotetext{
${ }^{14}$ In addition, in the context of French fiscal laws, the CEO can extract better benefits by paying him/herself in the form of dividends instead of wages.
} 
state-controlled companies. Based on this hierarchy of the degrees of management monitoring from one firm to another, the following results show how CEO pay evolved over time in an intra-firm perspective for each of these corporate control categories.

\subsection{Size of stakes and corporate control within firms}

The regressions of CEO compensation now include the reference firm size interacted with the categories of corporate control, as specified in Eq. (3). The non-controlled category is omitted, and the coefficient associated with the non-interacted reference firm size variable thus captures the impact for non-controlled firms. The others category is also omitted and the impact of the reference firm size for these types of control is then taken into account through the minority and majority control interacted terms. The results are displayed in Table 5. For the sake of brevity, control variables (i.e. firm size and CEO characteristics) and the indicator variables for the types of corporate control are no longer presented. As specified in Eq. (3), the reference firm size variable may correspond to the average of two to three metrics, chosen based on the results found in Table $3{ }^{15}$. The regressions are run with a within specification, which includes firm-specific fixed-effects.

\section{[nsert Table 5]}

Coefficients associated with the non-interacted reference firm size variable in Table 5 are positive and significant for the ratio of bonus, and the levels of cash and total compensation (Columns 2, 3, and 5). Hence, competition for CEO talent - as proxied by the reference firm — has had a significant effect on the variation of these pay components over the period, at least in non-controlled firms. The factor impact of the reference firm size is also economically substantial as, for instance, the 0.33 factor impact on total pay in Column 5 represents an increase by about 470 thousand euros for the median $\mathrm{CEO}^{16}$ between SP1 and SP3.

\footnotetext{
15 The reference firm size is measured by the lagged value of sales and the current firm value for salary and cash pay, plus the lagged firm value for total pay; it is measured by the current firm value for the ratio of bonus and by the lagged firm value for the ratio of LTIs.

${ }^{16}$ The median CEO total pay is 1,595 thousand euros in the entire sample.
} 


\subsubsection{Convergence in pay levels}

The interaction terms measure if a category of corporate control reacts more or less to a given change in the "size of stakes" compared to the omitted categories. For instance, from an efficient managerial labor market perspective, the growth of the reference firm size is expected to equally impact all categories, but in a governance institutions perspective, powerful CEOs are expected to make the most of transparency and benchmarking to increase their pay at a faster rate, albeit limited by "outrage constraint".

The main findings about the levels of pay (Columns 1, 3, and 5) are as follows. The corporate control categories that are associated with lower levels of pay initially ${ }^{17}$ in an interfirm perspective have over-reacted to the reference firm size growth. Specifically, the impact of the size of stakes has been significantly higher in majority-controlled firms for the three measures of the levels of pay (Columns 1,3, and 5), and in state-controlled firms for salary (Column 1) - the impact is also substantially positive but not significant on cash pay for the latter (Column 3). Conversely, the impact has been significantly lower for corporate control categories that provide their CEOs with the highest levels of pay initially. This is the case for firms controlled by passive families, associated with significantly negative impacts on the levels of pay (Columns 1, 3, and 5), and also for non-controlled firms in which salary has not increased with the reference firm size (Column 1).

The "size of stakes" does not have an equal impact on all firms, and the results thus contradict the efficient labor market hypothesis (H2.1a). However, the results do not confirm the managerial power hypothesis $(\mathrm{H} 2.2 \mathrm{a})$ either. Under this hypothesis, CEOs are expected to be more powerful and make the most of new pay transparency rules in non-controlled firms, as well as in firms with owner- or family-CEOs, and those controlled by passive families. Yet, the evolution of pay has not been faster for these corporate control categories; it has even been slower for the latter. Similarly, CEOs are expected to be slightly more powerful in minority- compared to majority-controlled firms, yet CEO pay increased at a faster rate in the latter than in the former.

The results call for additional explanations beyond the efficient market- and managerial power-based hypotheses. First, the pay increases in majority- and state-controlled firms can

\footnotetext{
17 The hierarchy of pay levels from one category to another, found in Table 4 for the entire period, are sensibly the same for SP1 only (not reported). Hence, these inter-firm effects can also be referred to as initial differences when pay transparency rules were implemented in SP1.
} 
be interpreted as a catch-up effect. Firms in these categories provide among the lowest levels of compensation initially in an inter-firm perspective; transparency since 2001 and benchmarking may then have brought some arguments for those most tightly-monitored CEOs to adjust their pay upward. Public opinion may specifically focus on top executive pay in firms controlled by the government, yet the salary, and to a lesser extent cash compensation, increased more markedly for these CEOs. Contrary to the powerful CEOs hypothesis, it is rather the less powerful and most-watched ones who make the most of transparency and benchmarking, not necessarily to jump to the right side of the pay distribution, but rather to get closer to median pay. This pattern in the evolution of pay is consistent with the hypothesis of a better functioning of labor market with imperfect information (H2.1b): transparency after 2001 facilitated pay benchmarking and resulted in a catching-up effect and a convergence in pay practices.

\subsubsection{The outrage constraint}

As for the most powerful CEOs, they receive the highest levels of pay initially between firms (i.e. in non-controlled firms and firms controlled by a passive family) but they get the lowest increases over time. This is also consistent with convergence and hypothesis (H2.1b), but this is well complemented by the outrage constraint hypothesis (H2.2b): the evolution of their pay slows down as they are placed under outsider scrutiny with the enforcement of transparency rules.

The results for the ratio of LTIs (Column 4) also provide support for the latter hypothesis. The reference firm size has almost no impact on this ratio, except for a positive but lowly substantial impact on minority- and majority-controlled firms. As already mentioned with the results found in Table 3, the specific feature of this pay component is that it is the only one associated with a remaining significant sub-period effect after controlling for the reference firm size in addition to other usual firm and CEO characteristics. It is indeed about nine points lower in SP3 compared to SP1, ceteris paribus. As argued earlier, this drop in LTIs cannot only be attributable to the immediate effects of the financial crisis, and it may instead be explained by the concomitant evolution of transparency rules. Since 2008, firms have been required to disclose the fair value of stock 
options and stock grants, thus placing the value of LTIs under the scrutiny of nonprofessional outsiders (such as the media or unions) ${ }^{18}$ for the first time.

The results then suggest that public disclosure hinders the value of equity-based pay granted to CEOs. Their drop after 2008 is consistent with the previous findings about subsiding pay levels in non-controlled firms and firms controlled by passive families, and it thus provides additional support for the outrage constraint hypothesis (H2.2b).

\subsubsection{Contingent-based pay and agency issues}

The non-interacted reference firm size variable has a positive and significant impact on cash and total compensation (Columns 3, and 5), but it is not different from zero for salary (Column 1). Its positive impact on cash and total pay is then mostly due to its impact on the ratio of bonus (Column 2). Consequently, competition for CEO talent - as proxied by the reference firm - has an overall impact on the levels of CEO pay through higher ratios of bonuses, but not in the form of higher base salaries.

The managerial labor market theoretical background of hypotheses (H1.1) and (H2.1a/b) explains why higher competition results in higher levels of pay, though it does not provide a rationale for why this should take the form of higher ratios of bonuses. Firms would more easily attract or retain their CEOs by ensuring them higher base salaries rather than through higher contingent bonuses.

The "size of stakes" view indeed relies on the GL model assumption that the reference firm size is a proxy for competitive intensity on the market for CEOs. But the reference firm size variable might also stand for other phenomena. In the present case, agency issues on the financial market would better account for the relation between the reference firm size and higher bonuses. The reference firm size may indeed increase with the development and deepening of financial markets, which in turn may be associated with the entrance of more activist shareholders. More equity shares held by professional investors induces intensified pressure to link CEO interests to outside minority shareholders wealth (Brav et al., 2008).

In addition, and contrary to other components of pay, the factor impact of the reference firm size is statistically the same for all categories of corporate control. In other words, the

\footnotetext{
18 Professional outsiders could estimate their fair value as the characteristics of the plans were disclosed before 2008.
} 
rise in the ratio of bonus has affected all firms, and the results in Table 3 show that it mainly occurred in SP2 - i.e. in the years following the disclosure of detailed cash pay packages. This latter pattern of a similar increase in all categories could be consistent with the efficientmarket hypothesis (H2.1a), provided it concerned the levels and not the ratios of pay. Attracting new CEOs require firms to ensure a minimum level of pay through higher base salaries, but this is not how the reference firm size has affected CEO pay. The results instead provide support for the agency-based hypothesis (H2.2c): pay transparency places pay packages under activist investors' scrutiny, resulting in increased ratios of bonuses. This result comes in addition to the earlier catch-up and outrage effects.

\subsubsection{Firm-specific CEOs and contagion effect}

The market-based perspective tested in this study follows the GL model. It relies on the assumption that the reference firm size is a proxy for CEO talent competition in the managerial labor market. This assumption is tested here based on CEOs that are identified as firm-specific, namely owner- and family-CEOs. These CEOs are attached to one specific firm and hence do not compete for outside opportunities. Consequently, there is less need to pay them competitively. The evolution of competition in the market for managerial talent, proxied by the reference firm size, is thus expected to have no impact on the evolution of their pay.

The results presented in Table 5 show that the reference firm size has a similar impact on owner- and family-CEOs pay as in other companies. Coefficients associated with ownerCEOs (the CEO category) are not different from zero, hence their pay is impacted as in the omitted Others category. Some of the coefficients associated with the Family CEO category are significantly negative, but on average, these coefficients only offset the impact of either minority- or majority-controls and, in the end, the factor impact in this category is similar to the one in non-controlled companies. Consequently, the evolution of pay for these firmspecific CEOs is similarly influenced by the reference firm size as in companies with professional CEOs. These results invalidate hypothesis (H2.1c) and question the marketbased interpretation of the reference firm size effect.

This finding first qualifies the earlier validated hypothesis $(\mathrm{H} 2.1 \mathrm{~b})$ of a market-driven convergence of pay practices. It then leads to expand the meaning of the reference firm size 
effect towards a nonmarket-driven contagion effect. The reference firm size provides an indication on the evolution of pay that executives and directors may find when benchmarking against a peer group. The market-based interpretation is that directors, while setting CEO pay, accept to keep up with the going rate of talent for retention or attraction reasons. But some earlier studies also show that firms may accept to keep up with pay practices in peer firms on the grounds of "perceived inequity" (Nagel, 2007). Hambrick and Finkelstein (1995) also argue that CEOs try to maximize their pay with the only constraint of "face legitimacy".

Piketty and Saez (2003) also suggest that "labor market institutions and social norms may play a role in the setting of compensation at the top". In the present case, transparency and the use of benchmarking lead directors and top executives to refer to median values in comparable firms which in turn define the pay level standards. These standards might as well define a new social norm of pay levels that are tolerable for public opinion: as long as all CEOs get higher pay packages, no one can personify the public outrage about inequality issues, and the levels of pay can adjust without hindrance to new standards.

In the end, contagion of pay practices occurs because CEOs can justify pay increases: their pay can rise on the grounds of social imitation and fairness, whether or not they compete on the managerial labor market.

\subsection{Robustness checks}

I use alternative methodologies for the results presented in Table 4 and Table 5 as robustness checks. First, I run two sets of regressions that respectively focus on the degree of control and on the monitor's identity, so as to check that these two cumulative typologies do not interfere with each other. The results confirm those found previously when both typologies are simultaneously included in the regressions ${ }^{19}$.

Second, I use a distinct methodology specified as follows: I run the regressions of pay on the reference firm size interacted with corporate control categories for the SP1 sub-sample on one hand, and for the SP3 sub-sample on the other hand, both with a between methodology. Firstly, the differences of pay packages from one corporate control category to another, as found in Table 4 on the entire sample period, are confirmed for both sub-

\footnotetext{
${ }^{19}$ Unreported tests that are referred to in this section are available upon request to the author.
} 
periods. Secondly, the results show that the differences between categories have diminished between SP1 and SP3, which is consistent with the convergence of pay practices found in Table 5. I also look at the evolution of coefficients from SP1 and SP3 for each category and run tests of equality. This test also yields results that are consistent with those presented earlier (i.e., faster increases for majority- and state-controls, and slower for passive families).

Third, I run tests to check if the reference firm size is related to competition in the managerial labor market, as stated in the GL model, or if it also provides information about agency issues in the financial market. For this purpose, I firstly use the yearly percentage of outsider CEOs on the panel ${ }^{20}$ as an alternative indicator for the intensity of competition for CEO talent. It is expected that the more CEOs are externally hired, the higher the competition. Secondly, I use the yearly-averaged share of equity held by activist minority investors ${ }^{21}$ as an indicator of pressure from outsider shareholders. I then run tests to identify a causality, in the Granger sense, between the reference firm size and these two variables. I find that the reference firm size causes the variations of both variables. In other words, the increase of the reference firm size contributes to explain higher competition in the managerial market, as captured by a higher share of outsider CEOs, but also the ability of outsider shareholders to voice their interests and curb agency costs, through higher activism. This robustness check shows that the managerial market-based interpretation cannot be fully rejected, but it also confirms that the impact of the reference firm size on CEO pay packages also reveals agency issues.

Lastly, I also run a distinct regression to test for the impact of the reference firm size on firm-specific CEOs pay, by sub-dividing the reference firm size variable into one for professional CEOs and one for owner- and family-CEOs. The coefficient values and a test of equality confirm that the reference firm size has a similar impact on both types of CEOs, and that the contagion effect it captures cannot only be driven by labor market forces.

\footnotetext{
${ }^{20}$ Measured by the share of CEOs in a given year that had less than two years with the firm when nominated as a CEO.

${ }^{21}$ Minority shareholders are investors holding less than 5 percent equity. Activist shareholders are defined as hedge funds (as in Brav and coauthors (2008)), and their equity shares are extracted from the Thomson One Banker — Ownership database.
} 


\section{CONCLUSION}

Individual CEO pay transparency has been compulsory for listed French companies since 2001. In this study, I test for the expected impacts of transparency based on hypotheses related to the functioning of the managerial labor market, on the one hand, and hypotheses related to governance institutions, on the other. The former specifically rely on the reference firm size that Gabaix and Landier (2008) use in their model as a proxy for competition for CEO talent, and I use the types of corporate control to test for alternative effects.

The evolution of pay packages after public disclosure show that newly available data has been used to benchmark pay practices in comparable firms. It yields an improved functioning of the managerial labor market in the form of convergence of pay practices from one firm to another. But the results of this study also show that this convergence is driven by forces not related to competition for CEO talent. Below-average CEOs can catch up to comparable firms on the grounds of perceived fairness and social imitation, and their pay rises do not trigger outrage as long as they do not stand as an outlier among peers (face legitimacy). Conversely, above-average CEOs experience outrage constraint as they have to curb the levels of their pay after it becomes publicly disclosed. Equity-based grants are similarly restrained after the disclosure of their fair value. Lastly, transparency also provides outsider shareholders with new data that they can use to curb agency costs and exert pressure on insiders. It has led to a surge in the ratios of bonuses, which as a matter of fact accounted for most pay rises during the sample period.

Gabaix and Landier (2008) provided a reference model to account for the evolution of CEO pay, and their main empirical contribution is to use a reference firm size to justify pay rises on the grounds of efficient labor market forces. Beyond the effects of transparency, this study argues that the reference firm size includes more information than simply the intensity of competition for CEO talent. The results show that this may also be a proxy for agency issues and higher pressure from activist investors in the financial market, and that it can also account for a contagion effect driven by new social standards in pay levels.

\section{REFERENCES}

Almeida, L., 2014. The level and structure of CEO compensation: Does ownership matter?. Revue $d^{\prime} E$ conomie Politique, 124(4), p. 653-666. 
Almeida, L., 2015. Who are the controlling shareholders? Degree and seniority of control, and CEO pay monitoring. EconomiX Working paper 2015-27.

Beatty, R. P., Zajac, E. J., 1994. Managerial incentives, monitoring, and risk bearing: A study of executive compensation, ownership, and board structure in initial public offerings. Administrative Science Quarterly, 39(2), p. 313-335.

Bebchuk, L. A., Fried, J. M., Walker, D. I., 2004. Pay withtout performance: The unfulfilled promise of executive compensation. Harvard University Press ed. Cambridge, MA: s.n.

Bereskin, F. L., Cicero, D. C., 2013. CEO compensation contagion: Evidence from an exogenous shock. Journal of Financial Economics, 107(2), p. 477-493.

Bizjak, J. M., Lemmon, M., Naveen, L., 2008. Does the use of peer groups contribute to higher pay and less efficient compensation?. Journal of Financial Economics, 90(2), p. 152-168.

Brav, A., Jiang, W., Partnoy, F., Thomas, R., 2008. Hedge fund activism, corporate governance, and firm performance. The Journal of Finance, 63(4), p. 1729-1775.

Chhaochharia, V., Grinstein, Y., 2009. CEO compensation and board structure. The Journal of Finance, 64(1), p. 231-261.

Core, J. E., Holthausen, R. W., Larcker, D. F., 1999. Corporate governance, chief executive officer compensation, and firm performance. Journal of Financial Economics, 51(3), p. 371-406.

Cyert, R. M., Kang, S.-H., Kumar, P., 2002. Corporate governance, takeovers, and topmanagement compensation: Theory and evidence. Management Science, 48(4), p. 453-469.

David, P., Kochhar, R., Levitas, E., 1998. The effect of institutional investors on the level and mix of CEO compensation. Academy of Management Journal, 41(2), p. 200-208.

DeAngelo, H., DeAngelo, L., 2000. Controlling stockholders and the disciplinary role of corporate payout policy: a study of the Times Mirror Company. Journal of Financial Economics, 56(2), p. 153-207.

DiPrete, T. A., Eirich, G. M., Pittinsky, M., 2010. Compensation benchmarking, leapfrogs, and the surge in executive pay. American Journal of Sociology, 115(6), p. 1671-1712.

Dyck, A., Zingales, L., 2004. Private Benefits of Control: An International Comparison. The Journal of Finance, 59(2), p. 537-600.

Dyl, E. A., 1988. Corporate control and management compensation: Evidence on the agency problem. Managerial and Decision Economics, Volume 9, p. 21-25.

Ertimur, Y., Ferri, F., Muslu, V., 2011. Shareholder activism and CEO pay. The Review of Financial Studies, 24(2), p. 535-592.

Ezzamel, M., Watson, R., 1998. Market comparison earnings and the bidding-up of executive cash compensation: Evidence from the United Kingdom. Academy of Management journal, 41(2), p. 221-231.

Faulkender, M., Yang, J., 2010. Inside the black box: The role and composition of compensation peer groups. Journal of Financial Economics, 96(2), p. 257-270.

Finkelstein, S., Boyd, B. K., 1998. How much does the CEO matter? The role of managerial discretion in the setting of CEO compensation. Academy of Management Journal, 41(2), p. 179199.

Gabaix, X., Landier, A., 2008. Why has CEO pay increased so much?. The Quarterly Journal of Economics, 123(1), p. 49-100.

Gabaix, X., Landier, A., Sauvagnat, J., 2014. CEO pay and firm size: An update after the crisis. The Economic Journal, 124(574), p. F40-F59.

Gomez-Mejia, L. R., Larraza-Kintana, M., Makri, M., 2003. The determinants of executive compensation in family-controlled public corporations. Academy of Management Journal, 46(2), p. 226-237.

Hambrick, D. C., Finkelstein, S., 1995. The effects of ownership structure on conditions at the top: The case of CEO pay raises. Strategic Management Journal, 16(3), p. 175-193. 
Hartzell, J. C., Starks, L. T., 2003. Institutional investors and executive compensation. The Journal of Finance, 58(6), p. 2351-2374.

Holmstrom, B., Kaplan, S. N., 2003. The state of U.S. corporate governance: What's right and what's wrong?. NBER Working Paper No. 9613.

Jensen, M. C., Murphy, K. J., 1990a. CEO incentives - It's not how much you pay, but how. Harvard Business Reviex, 68(3), p. 138-149.

Kaplan, S. N., 2008. Are U.S. CEOs Overpaid?. Academy of Management Perspectives, 22(2), p. 5-20.

Kramarz, F., Thesmar, D., 2013. Social networks in the boardroom. Journal of the European Economic Association, 11(4), p. 780-807.

La Porta, R., Lopez-De-Silanes, F., Shleifer, A., 1999. Corporate ownership around the world. Journal of Finance, 54(2), p. 471-517.

Lambert, R. A., Larcker, D. F., Weigelt, K., 1993. The structure of organizational incentives. Administrative Science Quarterly, 38(3), p. 438-461.

McConaughy, D. L., 2000. Family CEOs vs. nonfamily CEOs in the family-controlled firm: An examination of the level and sensitivity of pay to performance. Family Business Review, 13(2), p. 121-132.

Mehran, H., 1995. Executive Compensation Structure, Ownership, and Firm Performance. Journal of Financial Economics, 38(2), p. 163-84.

Nagel, G. L., 2007. Persistently underpaid CEOs and their influence on pay benchmarks. SSRN Electronic Journal 03; DOI:10.2139/ssm.971037.

Piketty, T., Saez, E., 2003. Income inequality in the United States, 1913-1998. The Quarterly Journal of Economics, 118(1), p. 1-39.

\section{TABLES}

Table 1 : Typologies of corporate control

\begin{tabular}{|c|c|}
\hline Categories & Description \\
\hline Controlling shareholder (C.S.) & $\begin{array}{l}\text { The largest shareholder sitting on the board and holding more than } 10 \% \text { of equity shares (on its } \\
\text { own, or in concert via shareholder agreements). }\end{array}$ \\
\hline \multicolumn{2}{|l|}{ Degree of control: } \\
\hline Non-controlled & No C.S. \\
\hline Minority control & The C.S. holds between $10 \%$ and $45 \%$ of equity shares. \\
\hline Majority control & The C.S. holds more than $45 \%$ of equity shares. \\
\hline \multicolumn{2}{|l|}{ Identity of monitor: } \\
\hline $\mathrm{CEO}$ & The C.S. is also the CEO of the company (CEO is the founder or an individual raider). \\
\hline Family CEO & $\begin{array}{l}\text { The C.S. is an heir family and the CEO is a member of the family (founding family or "family } \\
\text { raider"). }\end{array}$ \\
\hline Active family & $\begin{array}{l}\text { The C.S. is an heir family, at least one member of the family used to be a top executive in the } \\
\text { company. The CEO is external to the family. }\end{array}$ \\
\hline Passive family & $\begin{array}{l}\text { The C.S. is an heir family, family members may sit on the Board but none of them has ever been in a } \\
\text { top executive position in the company (indudes family conglomerates). The CEO is external to the } \\
\text { family. }\end{array}$ \\
\hline Public sector & The C.S. is the national government or a public agency. \\
\hline Parent company & $\begin{array}{l}\text { The C.S. is another company operating in the same industry (indude financial companies controlled } \\
\text { by another financial company). }\end{array}$ \\
\hline Investment company & The C.S. is an investment company (private equity, family office...) \\
\hline
\end{tabular}


Table 2: Descriptive statistics

Panel A: CEO pay and firm size

\begin{tabular}{|c|c|c|c|c|c|c|c|c|c|c|c|c|c|c|}
\hline \multirow{2}{*}{ Sample firms: } & \multicolumn{5}{|c|}{ Entire period } & \multicolumn{3}{|c|}{ SP1 (2001-2004) } & \multicolumn{3}{|c|}{ SP2 (2005-2008) } & \multicolumn{3}{|c|}{ SP3 (2009-2012) } \\
\hline & \multirow{2}{*}{ Mean } & \multirow[t]{2}{*}{ St. Dev. } & \multirow[t]{2}{*}{ Min } & \multirow[t]{2}{*}{ Median } & \multirow[t]{2}{*}{ Max } & \multicolumn{2}{|c|}{ St. Dev.Median } & \multirow[t]{2}{*}{ Max } & \multicolumn{2}{|c|}{ St. Dev.Median } & \multirow[t]{2}{*}{ Max } & \multicolumn{2}{|c|}{ St. Dev.Median } & \multirow[t]{2}{*}{$\operatorname{Max}$} \\
\hline CEO pay: & & & & & & & & & & & & & & \\
\hline Salary & 683 & 402 & 29 & 629 & 3,868 & 487 & 618 & 3,676 & 390 & 604 & 3,868 & 353 & 670 & 2,470 \\
\hline Bonus & 571 & 548 & 0 & 423 & 3,754 & 601 & 320 & 3,754 & 549 & 398 & 3,610 & 509 & 506 & 2,332 \\
\hline Cash compensation & 1,368 & 965 & 35 & 1,190 & 8,090 & 987 & 936 & 7,253 & 955 & 1,166 & 8,090 & 931 & 1,440 & 4,384 \\
\hline Long-term incentives & 913 & 1,684 & 0 & 310 & 16,857 & 1,853 & 266 & 16,150 & 1,948 & 383 & 16,857 & 1,151 & 233 & 9,920 \\
\hline Total compensation & 2,266 & 2,350 & 35 & 1,595 & 23,403 & 2,498 & 1,273 & 23,403 & 2,661 & 1,705 & 23,265 & 1,834 & 1,762 & 12,303 \\
\hline$\%$ Bonus / Salary & $75 \%$ & $53 \%$ & $0 \%$ & $74 \%$ & $263 \%$ & $51 \%$ & $60 \%$ & $242 \%$ & $55 \%$ & $78 \%$ & $263 \%$ & $51 \%$ & $79 \%$ & $252 \%$ \\
\hline \% LTI / Total comp. & $25 \%$ & $23 \%$ & $0 \%$ & $23 \%$ & $91 \%$ & $24 \%$ & $24 \%$ & $91 \%$ & $24 \%$ & $26 \%$ & $85 \%$ & $20 \%$ & $19 \%$ & $81 \%$ \\
\hline \multicolumn{15}{|l|}{ Firm size: } \\
\hline Sales (M€) & 11,475 & 20,334 & 2 & 2,626 & 167,611 & 18,458 & 2,942 & 128,857 & 20,987 & 2,395 & 155,946 & 21,159 & 2,626 & 167,611 \\
\hline Firm value (M€) & 19,122 & 46,916 & -142 & 3,583 & 403,274 & 47,837 & 3,173 & 380,552 & 48,978 & 3,745 & 357,724 & 44,045 & 3,743 & 403,274 \\
\hline \multicolumn{15}{|l|}{ Reference firm $\left(n^{\circ} 60\right)$ : } \\
\hline Ref. Sales (M€) & 2,076 & 502 & 1,427 & 2,288 & 2,622 & 33 & 1,490 & 1,503 & 373 & 2,288 & 2,480 & 27 & 2,563 & 2,622 \\
\hline Ref. Firm value (M€) & 3,240 & 848 & 1,780 & 3,551 & 4,183 & 273 & 2,210 & 2,413 & 493 & 3,980 & 4,106 & 285 & 3,654 & 4,183 \\
\hline Firm-year observations & & & \multicolumn{3}{|c|}{1,354} & \multicolumn{3}{|c|}{395} & \multicolumn{3}{|c|}{477} & \multicolumn{3}{|c|}{482} \\
\hline Num. of firms & & & \multicolumn{3}{|c|}{131} & \multicolumn{3}{|c|}{110} & \multicolumn{3}{|c|}{127} & \multicolumn{3}{|c|}{123} \\
\hline
\end{tabular}

Note: Amounts are in thousands of 2007 euros, unless otherwise specified.

Panel B: Average of indicator variables

\begin{tabular}{|c|c|c|c|c|}
\hline & Entire period & SP1 & SP2 & SP3 \\
\hline \multicolumn{5}{|l|}{ CEO characteristics: } \\
\hline CEO is chairman & 0.55 & 0.61 & 0.55 & 0.51 \\
\hline $\mathrm{CEO}$ is founder & 0.03 & 0.03 & 0.04 & 0.03 \\
\hline New insider CEO & 0.05 & 0.05 & 0.06 & 0.05 \\
\hline \multicolumn{5}{|l|}{ Degree of control: } \\
\hline Non-controlled & 0.24 & 0.23 & 0.28 & 0.22 \\
\hline Minority control & 0.40 & 0.41 & 0.36 & 0.42 \\
\hline Majority control & 0.36 & 0.36 & 0.36 & 0.36 \\
\hline Total & 1.00 & 1.00 & 1.00 & 1.00 \\
\hline \multicolumn{5}{|l|}{ Identity of monitor: } \\
\hline $\mathrm{CEO}$ & 0.12 & 0.15 & 0.13 & 0.10 \\
\hline Family, CEO & 0.10 & 0.12 & 0.09 & 0.09 \\
\hline Active family, non-CEO & 0.14 & 0.11 & 0.13 & 0.16 \\
\hline Passive family, non-CEO & 0.06 & 0.06 & 0.06 & 0.06 \\
\hline Public sector & 0.09 & 0.08 & 0.09 & 0.10 \\
\hline Company & 0.14 & 0.17 & 0.13 & 0.12 \\
\hline Investment company & 0.11 & 0.09 & 0.09 & 0.14 \\
\hline Total & 0.76 & 0.77 & 0.72 & 0.78 \\
\hline
\end{tabular}


Table 3: Witbin regressions of CEO compensation on control variables, sub-period dummies, and reference firm size

Note: Panel linear regressions for the levels of pay (Models 1, 2, 5, 6, 9, and 10); Tobit regressions for the ratios of contingent-based pay (Models 3, 4, 7, and 8). All regressions include firm-specific fixed-effects (within specification).

\begin{tabular}{|c|c|c|c|c|c|c|c|c|c|c|}
\hline & \multicolumn{2}{|c|}{ Ln(Salary) } & \multicolumn{2}{|c|}{$\%$ Bonus/Salary } & \multicolumn{2}{|c|}{ Ln(Cash compensation) } & \multicolumn{2}{|c|}{$\%$ LTIs/Total } & \multicolumn{2}{|c|}{ Ln(Total compensation) } \\
\hline & $(1)$ & $(2)$ & (3) & (4) & $(5)$ & (6) & $(7)$ & (8) & $(9)$ & (10) \\
\hline \multicolumn{11}{|l|}{ Firm size: } \\
\hline $\operatorname{Ln}(\text { Sales })_{\mathrm{t}-1}$ & $0.16(0.00)$ & $0.14(0.00)$ & & & $0.12(0.00)$ & $0.08(0.01)$ & & & $0.17(0.00)$ & $0.14(0.00)$ \\
\hline $\operatorname{Ln}(\mathrm{EV})$ & & & $0.12(0.00)$ & $0.10(0.00)$ & $0.10(0.00)$ & $0.11(0.00)$ & & & $0.10(0.00)$ & $0.12(0.00)$ \\
\hline $\operatorname{Ln}(E V)_{t-1}$ & $0.05(0.00)$ & $0.05(0.00)$ & & & & & $0.06(0.00)$ & $0.05(0.00)$ & $0.04(0.17)$ & $0.03(0.34)$ \\
\hline \multicolumn{11}{|l|}{ CEO characteristics: } \\
\hline $\mathrm{I}(\mathrm{CEO}$ is Chairman) & $0.06(0.00)$ & $0.06(0.00)$ & $-0.01(0.71)$ & $-0.01(0.76)$ & $0.01(0.64)$ & $0.02(0.35)$ & $-0.06(0.00)$ & $-0.06(0.00)$ & $-0.04(0.15)$ & $-0.03(0.26)$ \\
\hline $\mathrm{I}(\mathrm{CEO}$ is founder $)$ & $0.22(0.00)$ & $0.22(0.00)$ & $0.27(0.05)$ & $0.26(0.06)$ & $0.34(0.00)$ & $0.32(0.00)$ & $0.04(0.62)$ & $0.03(0.62)$ & $0.35(0.00)$ & $0.33(0.00)$ \\
\hline $\mathrm{I}(\mathrm{New}$ insider $\mathrm{CEO})$ & $-0.01(0.65)$ & $-0.01(0.75)$ & $-0.05(0.30)$ & $-0.06(0.26)$ & $-0.09(0.02)$ & $-0.08(0.03)$ & $0.00(0.90)$ & $0.01(0.79)$ & $-0.09(0.06)$ & $-0.08(0.10)$ \\
\hline \multicolumn{11}{|l|}{ Sub-periods: } \\
\hline $\mathrm{I}(\mathrm{SP} 2)$ & $0.06(0.00)$ & $0.01(0.81)$ & $0.16(0.00)$ & $-0.07(0.22)$ & $0.25(0.00)$ & $-0.01(0.75)$ & $0.02(0.09)$ & $0.00(0.92)$ & $0.26(0.00)$ & $0.01(0.92)$ \\
\hline $\mathrm{I}(\mathrm{SP} 3)$ & $0.12(0.00)$ & $0.03(0.51)$ & $0.19(0.00)$ & $-0.09(0.14)$ & $0.39(0.00)$ & $-0.01(0.86)$ & $-0.06(0.00)$ & $-0.09(0.00)$ & $0.30(0.00)$ & $-0.06(0.42)$ \\
\hline \multicolumn{11}{|l|}{ Reference firm size: } \\
\hline Ln(Ref. Sales) $)_{t-1}$ & & $0.11(0.01)$ & & & & $0.31(0.00)$ & & & & $0.20(0.02)$ \\
\hline Ln(Ref. EV) & & $0.05(0.37)$ & & $0.47(0.00)$ & & $0.34(0.00)$ & & & & $0.26(0.01)$ \\
\hline $\operatorname{Ln}(\text { Ref. EV })_{t-1}$ & & & & & & & & $0.05(0.13)$ & & $0.13(0.12)$ \\
\hline Intercept & $\mathrm{n} / \mathrm{a}$ & $\mathrm{n} / \mathrm{a}$ & $\mathrm{n} / \mathrm{a}$ & $\mathrm{n} / \mathrm{a}$ & $\mathrm{n} / \mathrm{a}$ & $\mathrm{n} / \mathrm{a}$ & $\mathrm{n} / \mathrm{a}$ & $\mathrm{n} / \mathrm{a}$ & $\mathrm{n} / \mathrm{a}$ & $\mathrm{n} / \mathrm{a}$ \\
\hline Firm fixed-effects & Yes & Yes & Yes & Yes & Yes & Yes & Yes & Yes & Yes & Yes \\
\hline Firm-year obs. & 1240 & 1240 & 1248 & 1248 & 1348 & 1348 & 1326 & 1326 & 1324 & 1324 \\
\hline Adj. $\mathrm{R}^{2}(\%)$ & 89.04 & 89.09 & $\mathrm{n} / \mathrm{a}$ & $\mathrm{n} / \mathrm{a}$ & 85.96 & 86.58 & $\mathrm{n} / \mathrm{a}$ & $\mathrm{n} / \mathrm{a}$ & 86.10 & 86.42 \\
\hline
\end{tabular}

p-values are in parenthesis. I(.) stands for the indicator function. EV stands for enterprise value (i.e. market value of equity, plus net debt). 
Table 4 : Between regressions of CEO compensation on firm and CEO characteristics, and on corporate control categories

\begin{tabular}{|c|c|c|c|c|c|}
\hline & $\begin{array}{c}\operatorname{Ln} \text { (Salary) } \\
(1) \\
\end{array}$ & $\begin{array}{c}\% \text { Bonus } \\
\text { /Salary } \\
(2)\end{array}$ & $\begin{array}{c}\text { Ln(Cash } \\
\text { comp.) } \\
(3)\end{array}$ & $\begin{array}{c}\text { \% LTIs } \\
/ \text { Total } \\
(4)\end{array}$ & $\begin{array}{c}\text { Ln(Total } \\
\text { comp.) } \\
(5)\end{array}$ \\
\hline \multicolumn{6}{|c|}{ Firm \& CEO characteristics: } \\
\hline $\mathrm{Ln}$ (Sales) & $0.95(0.00)$ & $0.73(0.02)$ & $1.14(0.00)$ & $0.13(0.19)$ & $1.28(0.00)$ \\
\hline $\operatorname{Ln}(\text { Sales })^{2}$ & $-0.02(0.00)$ & $-0.02(0.04)$ & $-0.03(0.00)$ & $0.00(0.23)$ & $-0.04(0.00)$ \\
\hline $\operatorname{Ln}(\mathrm{EV})$ & $0.01(0.82)$ & $0.09(0.02)$ & $0.06(0.10)$ & $0.04(0.01)$ & $0.12(0.00)$ \\
\hline S.d.(ROA) & $2.13(0.01)$ & $0.36(0.71)$ & $2.22(0.01)$ & $1.36(0.00)$ & $3.27(0.00)$ \\
\hline Ln(Age of firm) & $0.06(0.08)$ & $0.03(0.53)$ & $0.07(0.07)$ & $0.01(0.75)$ & $0.09(0.06)$ \\
\hline $\mathrm{I}(\mathrm{CEO}$ is Chairman $)$ & $0.13(0.04)$ & $0.19(0.02)$ & $0.24(0.00)$ & $0.07(0.05)$ & $0.30(0.00)$ \\
\hline $\mathrm{I}(\mathrm{CEO}$ is founder) & $0.63(0.00)$ & $-0.01(0.94)$ & $0.68(0.00)$ & $0.28(0.00)$ & $0.92(0.00)$ \\
\hline \multicolumn{6}{|l|}{ Degree of control: } \\
\hline \multicolumn{6}{|c|}{ I(Non-controlled) (omitted) } \\
\hline I(Minority control) & $-0.04(0.65)$ & $0.05(0.54)$ & $-0.05(0.64)$ & $-0.02(0.68)$ & $-0.15(0.21)$ \\
\hline I(Majority control) & $-0.12(0.11)$ & $-0.12(0.17)$ & $-0.23(0.01)$ & $-0.07(0.09)$ & $-0.40(0.00)$ \\
\hline \multicolumn{6}{|l|}{ Identity of monitor: } \\
\hline $\mathrm{I}(\mathrm{CEO})$ & $-0.40(0.00)$ & $-0.35(0.01)$ & $-0.60(0.00)$ & $-0.23(0.00)$ & $-0.80(0.00)$ \\
\hline I(Public sector) & $-0.30(0.00)$ & $-0.34(0.00)$ & $-0.44(0.00)$ & $-0.30(0.00)$ & $-0.68(0.00)$ \\
\hline I(Family CEO) & $0.16(0.08)$ & $-0.28(0.01)$ & $0.10(0.36)$ & $-0.23(0.00)$ & $-0.07(0.61)$ \\
\hline I(Passive family) & $0.49(0.00)$ & $0.00(0.97)$ & $0.56(0.00)$ & $0.15(0.02)$ & $0.72(0.00)$ \\
\hline \multicolumn{6}{|l|}{ I(Others) (omitted) } \\
\hline Intercept & $-2.96(0.04)$ & $-6.56(0.01)$ & $-4.71(0.01)$ & $-1.46(0.08)$ & $-6.27(0.00)$ \\
\hline Industry fixed-effects & Yes & Yes & Yes & Yes & Yes \\
\hline Firm fixed-effects & No & No & No & No & No \\
\hline Firm-year obs. & 1258 & 1258 & 1349 & 1349 & 1349 \\
\hline
\end{tabular}

p-values are in parentheses. I(.) stands for the indicator function.

Table 5: Within regressions of CEO compensation on the reference firm size interacted with corporate control types

\begin{tabular}{|c|c|c|c|c|c|}
\hline & Ln(Salary) & $\begin{array}{c}\% \text { Bonus / } \\
\text { Salary }\end{array}$ & $\begin{array}{c}\text { Ln(Cash } \\
\text { comp.) }\end{array}$ & $\begin{array}{c}\% \text { LTIs / } \\
\text { Total } \\
\end{array}$ & $\begin{array}{c}\text { Ln(Total } \\
\text { comp.) }\end{array}$ \\
\hline & (1) & (2) & (3) & (4) & $(5)$ \\
\hline \multicolumn{6}{|l|}{ Sub-periods: } \\
\hline $\mathrm{I}(\mathrm{SP} 2)$ & $0.00(0.91)$ & $-0.06(0.26)$ & $0.00(0.97)$ & $0.00(0.91)$ & $0.03(0.54)$ \\
\hline $\mathrm{I}(\mathrm{SP} 3)$ & $0.02(0.57)$ & $-0.08(0.17)$ & $0.00(0.98)$ & $-0.09(0.00)$ & $-0.02(0.74)$ \\
\hline Reference firm size & $0.03(0.64)$ & $0.53(0.00)$ & $0.55(0.00)$ & $-0.03(0.49)$ & $0.33(0.00)$ \\
\hline \multicolumn{6}{|c|}{ * I(Non-controlled) (omitted) } \\
\hline * I(Minority control) & $0.12(0.12)$ & $-0.10(0.46)$ & $0.02(0.83)$ & $0.09(0.08)$ & $0.23(0.04)$ \\
\hline * I(Majority control) & $0.28(0.00)$ & $-0.12(0.29)$ & $0.31(0.00)$ & $0.09(0.08)$ & $0.48(0.00)$ \\
\hline$* \mathrm{I}(\mathrm{CEO})$ & $0.06(0.45)$ & $-0.10(0.68)$ & $-0.16(0.12)$ & $0.07(0.54)$ & $-0.15(0.25)$ \\
\hline * I(Public sector) & $0.19(0.05)$ & $-0.19(0.11)$ & $0.15(0.20)$ & $0.00(1.00)$ & $0.00(0.99)$ \\
\hline * I(Family CEO) & $-0.15(0.09)$ & $0.15(0.29)$ & $-0.22(0.06)$ & $-0.05(0.50)$ & $-0.36(0.01)$ \\
\hline * I(Passive family) & $-0.41(0.00)$ & $-0.10(0.56)$ & $-0.36(0.01)$ & $0.00(0.95)$ & $-0.38(0.03)$ \\
\hline \multicolumn{6}{|l|}{ * I(Others) (omitted) } \\
\hline Firm \& CEO characteristics & Yes & Yes & Yes & Yes & Yes \\
\hline Type of corp. control & Yes & Yes & Yes & Yes & Yes \\
\hline Firm fixed-effects & Yes & Yes & Yes & Yes & Yes \\
\hline Firm-year obs. & 1240 & 1248 & 1348 & 1326 & 1324 \\
\hline
\end{tabular}

p-values are in parenthesis. I(.) stands for the indicator function. Ref. firm size $=\left[\ln (\text { Ref. sales })_{t-1}+\ln (\right.$ Ref. firm value $\left.)\right] / 2$, for Salary and Cash compensation; $=[\ln ($ Ref. sales $) t-1+\ln ($ Ref. firm value $)+\ln ($ Ref. firm value $) t-1] / 3$, for Total compensation; $=\ln ($ Ref. firm value $)$, for $\%$ Bonus; $=$ $\ln ($ Ref. firm value $) \mathrm{t}-1$, for $\%$ LTIs. 